\title{
ANALIZA ZACHOWAŃ ZDROWOTNYCH STUDENTÓW UNIWERSYTETU MEDYCZNEGO W ŁODZI
}

\section{ANALYSIS OF HEALTH BEHAVIORS OF STUDENTS OF THE MEDICAL UNIVERSITY OF LODZ}

\author{
Marcin Cierniak', Martyna Kruszyńska², Cezary Kułak², Dariusz Timler ${ }^{1}$ \\ 'Zakład Medycyny Ratunkowej i Medycyny Katastrof, Uniwersytet Medyczny w Łodzi \\ ${ }^{2}$ Katedra Polityki Ochrony Zdrowia, Uniwersytet Medyczny w Łodzi \\ ${ }^{3}$ Centrum Symulacji Medycznych, Uniwersytet Medyczny w Łodzi
}

DOI: https://doi.org/10.20883/ppnoz.2019.56

\section{STRESZCZENIE}

Wstęp. Według Światowej Organizacji Zdrowia zdrowie jest dobrostanem osiąganym w trzech wymiarach: fizycznym, umysłowym i społecznym. W opublikowanym w 1974 r. raporcie Marc Lalonde wyróżnił cztery grupy czynników wpływających na stan zdrowia ludności. Tymi czynnikami były obszary: biologii i genetyki, środowiska, organizacji ochrony zdrowia, a także stylu życia. Współcześnie szacuje się, że styl życia w ponad 50\% wpływa na stan zdrowia ludności.

Cel pracy. Badanie ma na celu analizę wybranych zachowań zdrowotnych podejmowanych przez młodzież akademicką z Uniwersytetu Medycznego w Łodzi. Materiał i metody. Badaniem objęto 200 studentów Uniwersytetu Medycznego w Łodzi. Zastosowany kwestionariusz ankiety zawierał 19 pytań. Uzyskane wyniki zostały poddane analizie statystycznej.

Wyniki. Nie mniej niż jedna trzecia badanych (31\%), ma kontakt z pacjentem niemal co dziennie, np.: w trakcie praktyk zawodowych bądź stażu. Jednocześnie niemal taki sam odsetek badanych (28\%) wskazuje, iz myje ręce przed kontaktem z pacjentem: czasami bądź nigdy. Więcej niż $80 \%$ ankietowanych deklaruje, iż uprawia aktywność fizyczną częściej niż jeden raz w tygodniu.

Dyskusja. Procent studentów próby badanej deklarujących palenie papierosów (20\%) jest mniejszy lub zbliżony w porównaniu do studentów środowisk medycznych pytanych o to zagadnienie, podobnie sytuacja wygląda w przypadku pytania o niezadowolenia z długości i jakości trwania swojego snu. W przypadku higienicznego mycia rąk procent studentów deklarujących, że wykonuje tę czynność prawidłowo jest dużo mniejszy niż w porównywanych pracach oryginalnych.

Wnioski. Procent osób deklarujących w ankiecie właściwe zachowania zdrowotne, jak odpowiednia higiena rąk, niepalenie papierosów czy higiena snu jest niezadowalający. Zasadnym jest pogłębienie profilaktyki w badanej grupie studentów kierunków medycznych.

Stowa kluczowe: zachowania zdrowotne, studenci.

ABSTRACT

Introduction. According to the World Health Organization, health is well-being achieved in three dimensions: physical, mental and social. In a report published in 1974, Marc Lalonde distinguished four groups of factors affecting the health of the population. These factors were the areas of biology and genetics, the environment, health care organization, and lifestyle. Today, it is estimated that lifestyle in more than $50 \%$ affects the health of the population. Aim of the study. The study aims to analyze selected health behaviors undertaken by academic youth from the Medical University of Lodz.

Material and methods. The study covered 200 students of the Medical University of Lodz. The survey questionnaire used contained 19 questions. The obtained results were subjected to statistical analysis.

Results. Not less than a third of respondents (31\%) have contact with the patient almost every day, e.g. during work placements or internships. At the same time, almost the same percentage of respondents (28\%) indicate that they wash their hands before contacting the patient: sometimes or never. More than $80 \%$ of respondents declare that they engage in physical activity more often than once a week.

Discussion. The percentage of students of the study sample declaring smoking (20\%) is smaller or similar compared to students of medical circles asked about this issue, the situation is similar in the case of dissatisfaction with the length and quality of their sleep. In the case of hygienic hand washing, the percentage of students declaring that they perform this activity correctly is much smaller than in the compared original works.

Conclusions. The percentage of people declaring appropriate health behaviors in the survey, such as proper hand hygiene, non-smoking cigarettes or sleep hygiene is unsatisfactory. It is reasonable to deepen prevention in the studied group of medical students.

\section{Wstęp}

Zachowania zdrowotne podejmowane przez studentów kierunków medycznych w trakcie trwania kształcenia warunkują nie tylko nawyki podejmowane w przyszłym życiu zawodowym, lecz mogą także wpływać na pacjentów, dla których przedstawiciele zawodów medycznych będą w przyszłości przykładem do naśladowania [1, 2].
Niezdrowy tryb życia zapoczątkowany przed podjęciem studiów może pogłębić się w trakcie kształcenia na kierunkach medycznych. Duże obłożenie nauką, kontakt z pacjentami będącymi w stanie terminalnym są czynnikami potęgującym stres i poziom niepokoju wśród studentów [3, 4]. Studenci medycyny podczas pierwszych lat 
nauki są bardziej zestresowani, a 30\% z nich doświadcza problemów natury psychicznej [5].

Jak pokazują badania, istnieje zależność pomiędzy poziomem aktywności fizycznej lekarzy a poziomem ich motywacji do zachęcania pacjentów do podejmowania aktywnego trybu życia. Podobnie sytuacja wygląda z paleniem tytoniu. Postawa lekarzy rodzinnych wobec palenia tytoniu wpływa na udzielanie pacjentom porad dotyczących porzucenia nałogu [6].

Prawidłowa higiena rąk personelu medycznego należy do najprostszych metod zapobiegania zakażeniom szpitalnym [7]. Kontakt z pacjentami powoduje, iż studenci są bezpośrednio narażeni na ryzyko wystąpienia infekcji, jednocześnie sami stanowią źródło zakażeń. Wykształcenie wśród przyszłych medyków nawyku prawidłowego mycia rąk, może przyczynić się do poprawy stopnia przestrzegania procedur higienicznych, który w dalszym ciągu pozostaje poniżej oczekiwań $[8,9]$.

Zachowanie dobrostanu psychicznego i fizycznego pozwala studentom sprostać wysokim wymaganiom kształcenia medycznego [10]. Jednak zdobywanie w toku studiów specjalistycznej wiedzy dotyczącej zdrowia nie zawsze przekłada się na stosowanie tej wiedzy w życiu osobistym [11].

\section{Cel}

Badanie ma na celu analizę wybranych zachowań zdrowotnych podejmowanych przez młodzież akademicką z Uniwersytetu Medycznego w Łodzi. Autorzy chcieli ocenić, jak wiele osób w próbie badanej przyznaje się np. do palenia papierosów, jak oceniają swój poziom aktywności fizycznej oraz to, jak często wykonują czynność mycia rąk, np. przed i po kontakcie z pacjentem.

\section{Materiał i metody}

Autorzy za pomocą sieci internetowej zaprosili studentów Uniwersytetu Medycznego w Łodzi do dobrowolnego i anonimowego wypełnienia kwestionariusza ankiety online. Ankieta została przygotowana z pomocą ogólnodostępnej platformy Google Forms. Zastosowany kwestionariusz ankiety zawierał 19 pytań dotyczących wybranych zagadnień zachowań zdrowotnych, a także zagadnienia mycia rąk w czasie i po kontakcie z pacjentem np. w trakcie realizacji praktyk studenckich. Dane zbierano przez okoto 6 miesięcy w roku ubiegłym. Uzyskane wyniki zostały poddane analizie statystycznej. Każde pytanie zawierało w sobie możliwości odpowiedzi TAK/NIE lub odpowiedzi skonstruowane tak, że student miał możliwość subiektywnej oceny, jak często wykonuje jakąś czynność np.: „zawsze, często, rzadko".

\section{Wyniki}

Sekcja "wyniki” została podzielona na opis oraz graficzne opracowanie pytań w kwestionariuszu ankiety.

W naszym badaniu znaczącą przewagę wśród respondentów stanowiły kobiety - 62\%. Zdecydowana większość (79\%) osób biorących udział w ankiecie to studenci pierwszych 3 lat studiów. Najwięcej (32\%) ankietowanych studiowało na roku pierwszym, a więc były to osoby niedoświadczone, dopiero rozpoczynające "przygodę ze studiami i medycyną". Szczegółowy rozkład respondentów w zależności od roku studiów przedstawia tabela 1.

Tabela 1. Rok studiów respondentów

\begin{tabular}{|c|c|c|}
\hline Rok studiów & N & $\%$ \\
\hline 1. & 63 & 32 \\
\hline 2. & 40 & 20 \\
\hline 3. & 53 & 27 \\
\hline 4. & 14 & 7 \\
\hline 5. & 20 & 10 \\
\hline 6. & 10 & 5 \\
\hline
\end{tabular}

Największe zainteresowanie badaniem osiągnięto na kierunku ratownictwo medyczne - 52\% ogółu respondentów. Studenci takich kierunków jak pielęgniarstwo, lekarski oraz wojskowo-lekarski udzielili od 8 do 13\% odpowiedzi w ankiecie. Z pozostałych kierunków uzyskano pojedyncze lub całkowity brak odpowiedzi (Tabela 2).

Tabela 2. Kierunek studiów respondentów

\begin{tabular}{|l|c|c|}
\multicolumn{1}{|c|}{ Kierunek studiów } & N & $\%$ \\
Lekarski & 31 & 16 \\
Wojskowo-Lekarski & 16 & 8 \\
\hline Ratownictwo Medyczne & 104 & 52 \\
\hline Dietetyka & 8 & 4 \\
Socjologia & 7 & 4 \\
Fizjoterapia & 0 & 0 \\
Kosmetologia & 0 & 0 \\
Analityka Medyczna & 1 & 1 \\
Stomatologia & 1 & 1 \\
Farmacja & 1 & 1 \\
Zdrowie Publiczne & 6 & 3 \\
Pielęgniarstwo & 25 & 13 \\
Położnictwo & 0 & 0
\end{tabular}

\section{Kontakt z pacjentem w czasie praktyk}

Wszyscy ankietowani studenci kierunków medycznych mają kontakt z pacjentami na swoich praktykach studenckich. Pozytywnym faktem jest to, iż zdecydowania większość z nich (57\%) ma kontakt z pacjentem co najmniej raz w tygodniu w trakcie trwania praktyk. Natomiast $34 \%$ 
ankietowanych ma kontakt z pacjentem raz w miesiącu lub rzadziej. Niemal co trzeci student (31\%) ma możliwość interakcji z pacjentem każdego dnia swoich praktyk, jednak podobna ilość respondentów wskazała, że taką szansę ma rzadziej niż raz w miesiącu.

\section{Mycie rąk}

Zdecydowana większość (79\%) ankietowanych studentów myje ręce częściej niż 6 razy w ciągu dnia. Jedynie 3\% wskazało, że czynność tę wykonuje mniej niż 3 razy dziennie.

Respondenci zostali również zapytani o mycie rąk przy okazji różnych sytuacji codziennych (Rycina 1) i związanych z kontaktem z pacjentem (Rycina 2).

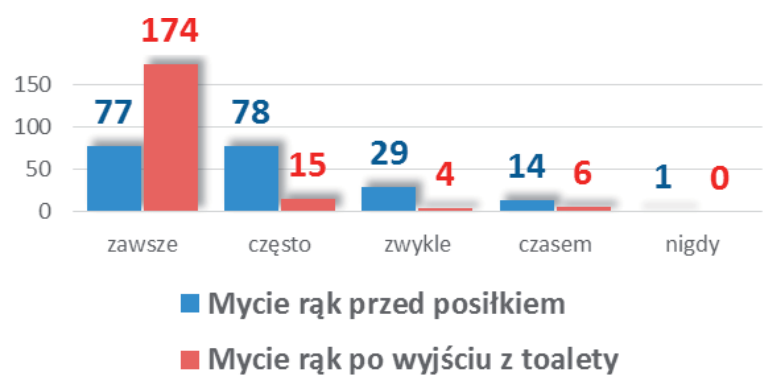

Rycina 1. Wykres zależności deklarowanego mycia rąk od sytuacji dnia codziennego

Zaledwie 39\% ankietowanych studentów stosuje profilaktykę wielu chorób przenoszonych drogą pokarmową poprzez mycie rąk zawsze przed każdym posiłkiem. Taka sama liczba respondentów robi to często. 7\% ankietowanych myje ręce przed posiłkiem: „czasami”, zaś „zwykle” robi to $15 \%$. Jedynie dwoje studentów przyznało, że nigdy nie myje rąk przed posiłkiem.

Zdecydowana większość ankietowanych (87\%) zachowuje higienę w sposób prawidłowy, myjąc ręce po każdym wyjściu z toalety. Natomiast pozostałe $13 \%$ nie zawsze to robi.

Po każdym przyjściu do domu "zawsze” ręce myje mniej niż połowa (44\%) ankietowanych. "Często" robi to zaś co piąty student. Podobny odsetek deklaruje, że robi to "czasem" lub „zwykle”. Jedynie 2\% nie robi tego nigdy.

Mniej niż połowa ankietowanych (43\%) deklaruje, iż usuwa nabytą florę bakteryjną rąk przed kontaktem z pacjentem. Zdecydowana jednak większość ankietowanych (67\%) deklaruje, iż myje ręce zawsze po każdym kontakcie z pacjentem, natomiast 33\% osób próby badanej deklaruje, iż nie stosuje się do zaleceń i nie zawsze myje ręce po kontakcie z pacjentem.

Zdecydowana większość studentów (94\%), którzy deklarowali w ankiecie, że korzystają z możliwości mycia rąk w toaletach publicznych, robi to w prawidłowy sposób, korzystając z mydła z dozownika lub własnego środka de- zynfekcyjnego. Natomiast 2\% ankietowanych w ogóle nie myje rąk w toaletach publicznych. Co dwudziesty student wykonuje tylko spłukanie rąk wodą.

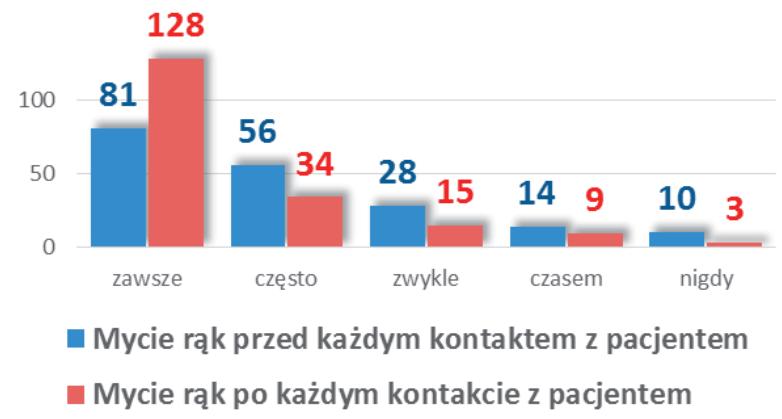

Rycina 2. Deklarowane mycie rąk przez studentów w zależności od etapu kontaktu z pacjentem

\section{Aktywność fizyczna}

Zdecydowana większość ankietowanych studentów (71\%) ocenia, iż uprawia aktywność fizyczną zgodnie z zaleceniami, a więc 30 min na około $70 \%$ maksymalnego wysiłku (Rycina 3). Jednocześnie 81\% ankietowanych studentów deklaruje, iż uprawia aktywność fizyczną co najmniej raz w tygodniu. Przy czym niemal codziennie aktywność podejmuje jedynie 16\%. Tylko 19\% ankietowanych deklaruje, iż uprawia aktywność fizyczną rzadziej niż raz w tygodniu.

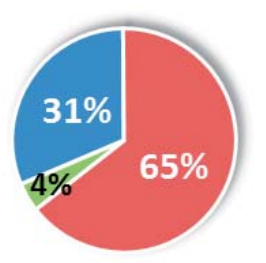

\section{" wystarczająca " niewystarczająca " nie wiem}

Rycina 3. Samoocena aktywności fizycznej respondentów

Zdecydowana większość (64\%) respondentów uważa, iż ich aktywność fizyczna jest niewystaczająca. Tylko 31\% osób jest zadowolonych ze swojego obecnego poziomu aktywności. Większość ankietowanych studentów (57\%) deklaruje, iż ich sprawność fizyczna jest na poziomie dobrym lub bardzo dobrym. Tylko 4\% studentów opisuje swoją wydolność fizyczną jako złą (Rycina 4).

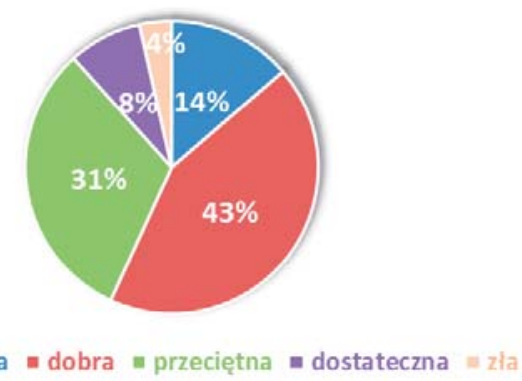

Rycina 4. Samoocena poziomu sprawności fizycznej respondentów 


\section{Palenie papierosów}

Ponad $80 \%$ studentów deklaruje, iż nie pali papierosów. Do wypalania mniej niż 5 papierosów dziennie przyznaje się niecałe $10 \%$ ankietowanych. Tylko $3 \%$ wypala więcej niż 10 papierosów w ciągu dnia (Rycina 5).

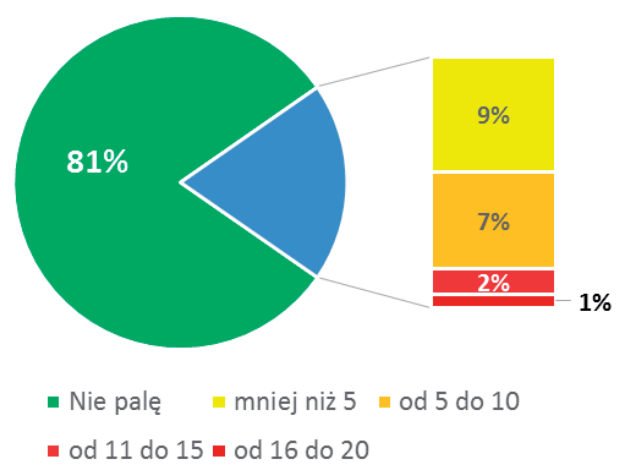

Rycina 5. Palenie papierosów wśród respondentów

\section{Sen}

Większość ankietowanych (63\%) uważa, że śpi zbyt mało, aby zaspokoić potrzeby swojego organizmu.

Zdecydowana mniejszość ankietowanych studentów przestrzega regularności snu codziennie (14\%). Najczęściej wskazywano, że regularność snu jest możliwa do przestrzegania jedynie w weekendy. Większość ankietowanych wskazuje na trudności w pilnowaniu regularności swojego snu (Rycina 6).

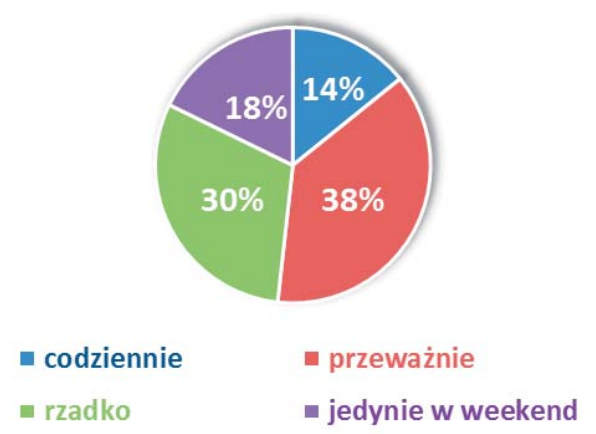

Rycina 6. Deklarowana regularność snu respondentów

\section{Dyskusja}

Studenci ankietowanej próby w większości deklarują, iż nie palą papierosów (80\%). Natomiast $20 \%$ z nich odpowiedziało $w$ ankiecie, że pali papierosy. Jest to mniejszy wynik niż w przypadku badań Kruka (36\%), który także badał odsetek studentów palących. Nie mniej jednak byli to studenci różnych kierunków studiów, przeważnie niemedycznych. Co ciekawe, w grupie wiekowej poniżej 25 lat zanotował większy odsetek palących niż wśród starszych ankietowanych [12]. W naszym badaniu niemal wszyscy ankietowani byli w wieku poniżej 25 r.ż. Odnosząc się natomiast do badań Siemińskiej, która badała zjawisko palenia właśnie w środowisku studentów kierunków medycznych, można zauważyć, że odsetek osób palących w podobnej grupie wiekowej jest niemal taki sam (21\% vs $20 \%$ ), natomiast wśród starszych studentów ww. badaczka zauważyła niższy odsetek osób palących (13\%), jednocześnie potwierdzając pozytywny wpływ studiów medycznych na obniżanie się odsetka osób palących [13, 14]. Jednak wszystkie powyższe wyniki są daleko odbiegające od wyników Szczerbińskiego, który w 2010 r. badał odsetek osób palących w jednej ze szkół wyższych wychowania fizycznego, gdzie odsetek ten wyniósł aż 82\% [15].

Większość ankietowanych studentów (57\%) deklaruje, iż ich aktywność fizyczna jest na poziomie dobrym lub bardzo dobrym. Tylko $4 \%$ studentów opisuje swoją aktywność fizyczną jako złą. Jest to znacznie niższy wynik niż w badaniach Sochockiej [16], która badała aktywność fizyczną wśród studentów kierunków zarówno medycznych, jak i niemedycznych. W badaniach tej autorki aż 79,5\% respondentów uważało, iż są sprawni i aktywn fizycznie. Jednocześnie respondenci naszego badania w większości (64\%) uważają swoją aktywność fizyczną za niewystarczającą i chcieliby ją poprawić. W badaniach autorki 12,4\% procent ankietowanych podejmuje aktywność fizyczną codziennie, w naszej próbie badanej było to $16 \%$, natomiast $36 \%$ stanowili studenci podejmujący aktywność częściej niż raz w tygodniu, w badaniach Sochockiej było to $25 \%$. Niemal ten sam procent studentów w obydwóch badaniach deklarował, że podejmuje aktywność raz lub kilka razy w miesiącu (około $18 \%$ w obydwóch badaniach). Procent osób oceniających dobrze swoją aktywność fizyczną jest natomiast znacznie mniejszy niż np. wśród studentów akademii wychowania fizycznego. W badaniach Prusik procent ten wyniósł nawet 94,8\% [17].

Zdecydowana większość (63\%) ankietowanych studentów uważa, iż długość ich snu nie wystarcza, aby organizm mógł wypocząć. Podobny odsetek (47,9\%) studentów niezadowolonych ze swojego snu został odnotowany w badaniach Kasperczyka, który badał jakość snu w populacji studentów Śląskiego Uniwersytetu Medycznego. Podobny odsetek (około 66-69\%) ankietowanych w obydwóch badaniach wskazywało na sen nieregularny oraz na rzadkie przestrzeganie regularności snu [18].

Zdecydowana większość ankietowanych (87\%) zachowuje higienę w sposób prawidłowy, myjąc ręce po każdym wyjściu z toalety. Natomiast pozostałe 13\% nie zawsze to robi. Jest to zdecydowanie lepszy wyniki niż w badaniach Klimberg (100\%), która badała podobne zagadnienia 
wśród studentów medycyny. Zaledwie 39\% ankietowanych studentów naszego badania stosuje profilaktykę wielu chorób przenoszonych drogą pokarmową poprzez mycie rąk przed każdym posiłkiem. 7\% ankietowanych myje ręce przed positkiem "czasami”. W badaniach Klimberg było to aż 96\%. Zdecydowana większość ankietowanych (67\%) deklaruje, iż myje ręce zawsze po każdym kontakcie z pacjentem, natomiast 33\% osób próby badanej deklaruje, iż nie stosuje się do zaleceń i nie zawsze myje ręce po kontakcie z pacjentem. Wynik ten jest także znacznie gorszy od badań Klimberg, gdzie ręce po każdym kontakcie z pacjentem myje około $84 \%$ ankietowanych. Mniej niż połowa ankietowanych próby badanej (43\%) deklaruje, iż usuwa nabytą florę bakteryjną rąk przed kontaktem z pacjentem. W badaniach Klimberg odsetek ten jest już niewiele wyższy i wynosi 52\% osób deklarujących mycie rąk przed założeniem rękawiczek i kontaktem z pacjentem [19].

\section{Wnioski}

- $\quad$ Procent studentów próby badanej deklarujący prawidłową higienę rąk jest wysoki, ale niezadowalający.

- Liczba osób deklarujących palenie papierosów jest porównywalna z innymi środowiskami studentów kierunków medycznych.

- Procent osób deklarujących zadowolenie ze swojego snu jest wysoki.

- Zasadne byłoby dalsze propagowanie odpowiednich zachowań zdrowotnych wśród studentów kierunków medycznych.

\section{Oświadczenia}

Oświadczenie dotyczące konfliktu interesów

Autorzy deklarują brak konfliktu interesów.

\section{Źródła finansowania}

Autorzy deklarują brak źródeł finansowania.

\section{Piśmiennictwo}

1. Voigt et al. Consumption of alcohol, cigarettes and illegal substances among physicians and medical students in Brandenburg and Saxony (Germany), BMC Health Services Research. 2009; 9: 219.

2. Terebessy et al. Medical students' health behaviour and self-reported mental health status by their country of origin: a cross-sectional study, BMC Psychiatry BMC. 2016; 16: 171.

3. Paro et al. Health-related quality of life of medical students, Medical Education. 2010; 44: 227-235.

4. Liselotte $\mathrm{N}$ et al. Medical Student Distress: Causes, Consequ ences, and Proposed Solutions, Mayo Clin Proc. 2005; 80(12): 1613-1622.
5. Midtgaard $\mathrm{M}$ et al. Mental health treatment needs for medical students: a national longitudinal study, European Psychiatry. 2008; 23: 505-511.

6. Barengo NC, Sandström HP, Jormanainen VJ et al. Attitudes and behaviours in smoking cessation among general practitioners in Finland 2001, Soz.-Präventivmed. 2005; 50: 355-360.

7. https://www.cdc.gov/mmwr/preview/mmwrhtml/ rr5116a1.htm

8. Garus-Pakowska. Wpływ obciążenia pracą na przestrzeganie procedur higienicznych przez personel medyczny, Medycyna Pracy. 2011; 62(4): 369-376.

9. Gawron-Skarbek A i wsp. Negatywne wzorce zachowań studentów. Część III. Respektowanie norm higienicznych, Probl Hig Epidemiol. 2011; 92(3): 466-473.

10. Riemenschneider et al. Do socio-cultural factors influence medical students' health status and healthpromoting behaviors? A cross-sectional multicenter study in Germany and Hungary, BMC Public Health. 2016; 16: 576.

11. Kusma B, Quarcoo D, Vitzthum K et al. Berlin's medical students' smoking habits, knowledge about smoking and attitudes toward smoking cessation counseling. J Occup Med Toxicol. 2010; 5: 9.

12. Kruk W, Hubert-Lutecka A, Zając K i wsp. Palenie tytoniu przez studentów - skala problemu Medycyna Ogólna i Nauki o Zdrowiu, 2014; Tom 20, Nr 4, 433-438.

13. Siemińska A, Jassem-Bobowicz JM, Uherek M i wsp. Postawy wobec palenia tytoniu wśród studentów I i VI roku medycyny z rocznika studiów 2002-2008 Pneumonol. Alergol Pol. 2009; 77: 371-379.

14. Siemińska A, Jassem J, Uherek M i wsp. Postawy wobec palenia tytoniu wśród studentów pierwszego roku medycyny Pneumonol. Alergol. Pol. 2006; 74: 377-382.

15. Szczerbiński R, Karczewski J. Wybrane zachowania Wybrane zachowania zdrowotne studentów Wyższej Szkoły Wychowania Fizycznego i Turystyki w Supraślu -palenie papierosów i spożywanie napojów alkoholowych. Hygeia Public Health 2010; 45(2): 185-188.

16. Sochocka L, Wojtyłko A. Aktywność fizyczna studentów studiów stacjonarnych kierunków medycznych i niemedycznych. Environmental Medicine. 2013; 16(2): 53-58.

17. Katarzyna Prusik K, Zaporozhanov V, Görner K i wsp. Stan aktywności fizycznej w stylu życia studentów akademii wychowania fizycznego i sportu w Gdańsku. Проблеми фізичного виховання і спорту. 2009; № 12.

18. Kasperczyk J, Jośko J. Analiza czynników odpowiedzialnych za złą jakość snu u studentów Śląskiego Uniwersytetu Medycznego. Hygeia Public Health. 2012; 47(2): 191-195.

19. Klimberg A. Wiedza studentów medycyny nt. higieny rąk w zakładach opieki zdrowotnej. Probl Hig Epidemiol. 2007; 88(1): 60-63.

Zaakceptowano do edycji: 15.12 .2019 Zaakceptowano do publikacji: 15.02 .2020

Adres do korespondencji:

Zakład Medycyny Ratunkowej

ul. Pomorska 251

92-209 Łódź

tel. 792335325 